\title{
PENERAPAN METODE INKUIRI MELALUI PENGAMATAN SITUS SEJARAH DI KOTA BIMA UNTUK MENINGKATKAN HASIL BELAJAR DAN MENUMBUHKEMBANGKAN KECINTAAN PADA BANGUNAN BERSEJARAH ( Studi Kasus Pada Siswa kelas XI IPS 1 MAN 2 Kota Bima).
}

\author{
Ilmiawan Mubin \\ Pendidikan Sejarah, Universitas Muhammadiyah Mataram, ilmiawanbima@yahoo.co.id
}

\section{INFO ARTIKEL}

RiwayatArtikel:

Diterima: 12-10-2017

Disetujui: 16-10-2017

\section{Kata Kunci:}

1. Situs Sejarah,

2. Hasil Belajar,

3. Kecintaan Pada Bangunan Bersejarah,

4. Metode Inkuiri.

\section{A. LATAR BELAKANG}

Pendidikan pada dasarnya merupakan usaha sadar dan terencana untuk mewujudkan suasana belajar dan proses pembelajaran agar peserta didik secara aktif mengembangkan potensi dirinya untuk memiliki kekuatan spiritual keagamaan, pengendalian diri, kepribadian, kecerdasan, akhlak mulia, serta keterampilan yang diperlukan dirinya, masyarakat, bangsa dan Negara (Depdiknas, 2007:7). Dengan kata lain pendidikan merupakan proses untuk membantu manusia dalam mengembangkan dirinya sehingga mampu menghadapi setiap perubahan yang terjadi. Dalam rangka pembangunan manusia seutuhnya, pembangunan dibidang pendidikan merupakan sarana dan wahana yang sangat baik dalam pembinaan sumber daya manusia. Oleh karena 
itu, bidang pendidikan perlu mendapat perhatian, penanganan, dan prioritas secara intensif baik oleh pemerintah, keluarga, dan pengelola pendidikan khususnya. Maka pemerintah telah melakukan berbagai upaya dalam ranmgka meningkatkan mutu pendidikan nasionalnya. Meskipun hasilnya belum menggembirakan, namun berbagai upaya perbaikan pendidikan terus dilakukan antara lain perubahan kurikulum, penataranpenataran, pengadaan buku-buku teks/paket, media pengajaran, perbaikan sarana dan prasarana pendidikan, peningkatan metode dan strategi pembelajaran (Haar Tilaar, 2010: 18). Sedangkan menurut (Suyatno, 2003:47), upaya-upaya perbaikan pendidikan desentralisasi pendidikan, relevansi kurikulum pendidikan dan akuntabilitas institusi akan menjadi permasalahan pembangunan pendidikan di Indonesia, baik pada saat sekarang maupun masa yang akan datang. Permasalahan pendididikan merupakan salah satu dimensi strategi yang sangat penting untuk dipikirkan secara serius guna membangun bangsa dan masa depan yang baik'

Oleh karena itu untuk memperlancar proses pendidikan perlu suatu wadah atau lembaga yang disebut sekolah yakni lingkungan pendidikan yang menyediakan bermacam kesempatan bagi siswa untuk melakukan berbagai kegiatan belajar sehungga siswa memperoleh pengalaman pendidikan. Dengan demikian mendorong pertumbuhan dan perkembangan kearah suatu tujuan yang dicita-citakan dalam tujuan pendidikan. Sebagaimana diamanatkan dalam UUD 1945 yaitu melindungi segenap bangsa Indonesia dan seluruh tumpah darah Indonesia dan untuk memajukan kesejahteraan umum, mencerdaskan kehidupan bangsa dan ikut melaksanakan ketertiban dunia yang berdasarkan kemerdekaan (Depdiknas, 2005:7). Maka peranan sentral pendidikan sebagai alat mencerdaskan generasi muda Indonesia tidak dapat diremehkan.

Maka berangkat dari hal tersebut, jika dilihat dari segi pembangunan bangsa pengajaran sejarah adalah sangat penting, sebab melalui pengajaran sejarah, nilainilai yang berkembang pada generasi terdahulu bisa diwariskan dan dilestarikan pada generasi berikutnya (khususnya pada generasi muda masa kini). Pelestarian nilai-nilai sejarah bukan saja untuk integrasi individu ke dalam kelompok, yakni sebagai bekal kekuatan untuk menghadapi masa kini dan masa yang akan datang. Pada konteks ini sejarah berperan dalam menanamkan konsepkonsep nasionalisme, persatuan, solidaritas dan integrasi nasional. Bagi peserta didik tidak dapat dipungkiri bahwa pembelajaran sejarah disekolah adalah cara terbaik untuk menanamkan konsep dan nilai-nilai (Susanto, 2011:3). Hal ini sesuai juga yang termuat di KTSP sejarah bahwa pelajaran sejarah disekolah mengandung dua misi yakni untuk pendidikan intelektual dan pendidikan nilai, pendidikan kemanusiaan, pendidikan pembinaan moralitas, jati diri, nasionalisme, identitas bangsa (BNSP, 2007:8)

Dalam kurikulum sejarah kegiatan pembelajaran dirancang untuk memberikan pengalaman belajar yang melibatkan proses mental dan fisik melalui interaksi antara peserta didik, peserta didik dengan guru, lingkungan dan sumber belajar lainnya dalam rangka pencapaian kompetensi dasar. Pengalaman belajar yang dimaksud dapat terwujud melalui penggunaan pendekatan pembelajaran yang bervariasi dan berpusat pada peserta didik.Pengalaman belajar memuat kecakapan hidup yang perlu dikuasai oleh peserta didik (BSNP, 2007). Atas dasar amanah dari kurikulum sejarah yang berbasis kompetensi tersebut, yang mana dalam pembelajaran sejarah bersifat mengaktifkan siswa (bersifat student oriented), maka sudah selayaknya pembelajaran sejarah sudah diperbaiki, terutama agar lebih memberikan rangsangan dan kesempatan terjadinya proses kreatif dan aktivitas siswa dalam belajar, sehingga dari kondisi semacam itu diharapkan akan dapat meningkatkan mutu pembelajaran sejarah, khususnya di MAN 2 Kota Bima, untuk itulah maka solusinya adalah dengan mengoptimalkan pembelajaran sejarah berbasis situs sejarah untuk meningkatkan hasil belajar siswa dan untuk menumbuhkembangkan kecintaan pada bangunan bersejarah, dilingkungan sekitar dalam proses belajar siswa dan juga akan tertantang dalam mengikuti proses pembelajaran, mereka akan lebih aktif dan kreatif, misalnya dalam mencari sumber-sumber buku, dokumen-dokumen, bukti-bukti sejarah berupa peninggalan bangunan atau referensi-referensi lainnya sebagai sumber informasi sejarah. Dengan aktif dan kreatifnya siswa, baik dalam mencari sumber-sumber, 
mengamati objek sumber, maupun dalam diskusi sebagai upaya dalam mencari pemecahan masalah, maka siswa akan benar-benar memahami materi pelajaran, disamping juga siswa merasa senang, tertantang dan merasa dihargai, peserta didik mampu berfikir sendiri mengapa dan bagaimana peristiwa itu terjadi di masa lampau dan disamping itu siswa akan semakin cinta dengan benda peninggalan sejarah karena berhubungan langsung dengan obyek yang dipelajarinya.

\section{B. METODE PENELITIAN}

Sesuai dengan konteks permasalahan yang dikaji maka penelitian ini adalah merupakan penelitian tindakan kelas (Action Research in Classroom). Mengapa peneliti menggunakan penelitian ini karena didasarkan atas asumsi bahwa guru memiliki komitmen yang sangat kuat untuk senantiasa memperbaiki sistem serta meningkatkan kinerja dalam rangka memperbaiki atau meningkatkan mutu proses dan hasil kegiatan pembelajaran (Sarwiji Suwandi, 2008:8). Maka dengan adanya penelitian ini dapat membantu guru mata pelajaran sejarah untuk melakukan refleksi tentang berbagai hal permasalah yang ada pada proses kegiatan belajar mengajar atau pembelajaran sejarah. Jenis penelitian ini merupakan penelitian yang sangat tepat untuk meningkatkan kualitas pembelajaran sejarah pada khususnya dan peningkatan kualitas pendidikan pada umumnya. Tujuan penelitian tindakan kelas adalah untuk menyelesaikan masalah melalui suatu perbuatan nyata, bukan hanya mencermati fenomena tertentu kemudian mendeskripsikan apa yang terjadi dengan fenomena tersebut.

\section{HASIL DAN PEMBAHASAN}

\section{HASIL PENELITIAN}

a) Hasil belajar siswa kelas XI IPS 1 MAN 2 Kota Bima pada pembelajaran sejarah dengan menggunakan Metode Inkuiri Melalui Pengamatan Situs Sejarah di Kota Bima pada Siklus I .

Hasil pembelajaran sejarah dengan pengamatan situs sejarah di kota Bima dengan menggunakan metode Inkuiri pada siklus I ini berdasarkan data yang didapat, menunjukan bahwa siswa yang mencapai KKM diatas 75 atau nilai diatas 75 sebanyak 23 orang siswa dengan persentase $65,72 \%$. Sebaliknya siswa yang belum mencapai KKM mendapatkan nilai kurang dari 75 sebanyak 12 orang siswa dengan persentase 34,28\% dan nilai rata-rata pada siklus I mencapai 75,02. Berdasarkan hasil tersebut dapat diketahui bahwa setelah diadakan tindakan pada siklus I sudah menunjukan hasil belajar yang bagus akan teapi ketuntasan maksimal belum dapat tercapai.

b) Kecintaan siswa kelas XI IPS 1 MAN 2 Kota Bima Pada Bangunan bersejarah dengan penerapan metode Inkuiri Melalui Pengamatan Situs Sejarah di Kota Bima pada Siklus I

Pelaksanaan pembelajaran dengan penerapan metode Inkuiri pada siswa kelas XI IPS 1 MAN 2 Kota Bima. Setelah diadakan pengisian angket secara individual hasilnya belum begitu memuaskan data terlampir. Siswa yang mendapat skor sama atau diatas 80 berjumlah 27 orang siswa dengan persentase $77,14 \%$. Sedangkan siswa yang mendapat skor kurang dari 80 berjumlah 8 orang siswa dengan persentase $22,86 \%$ dan nilai rata-rata skor 80,54 .

c) Hasil belajar siswa kelas XI IPS 1 MAN 2 Kota Bima dengan menggunakan Metode Inkuiri Melalui Pengamatan Situs Sejarah Bima pada Siklus II.

Hasil pembelajaran dengan menggunakan metode Inkuiri pada siklus II ini berdasarkan data yang didapat, menunjukan bahwa siswa yang mencapai KKM diatas 75 atau nilai diatas 75 sebanyak 30 orang siswa dengan persentase 85,71\%. Sebaliknya siswa yang belum mencapai KKM mendapatkan nilai kurang dari 75 sebanyak 5 orang siswa dengan persentase 14,29\%. Kemampuan siswa memahami materi tentang kerajaankerajaan yang bercorak islam dengan Sub materi Kesultanan Bima pada siklus II dengan nilai rata-rata mencapai 79. Berdasarkan hasil tersebut dapat diketahui bahwa setelah diadakan tindakan pada siklus II sudah menunjukan hasil belajar yang bagus akan teapi ketuntasan maksimal belum dapat tercapai.

d) Kecintaan siswa kelas XI IPS 1 MAN 2 Kota Bima dengan penerapan metode Inkuiri melalui pengamatan situs sejarah di Kota Bima pada Siklus II.

Pelaksanaan pembelajaran dengan penerapan metode Inkuiri pada siswa kelas XI IPS 1 MAN 2 Kota Bima. Setelah diadakan pengisian angket secara individual hasilnya belum begitu memuaskan data terlampir. Siswa yang mendapat skor sama atau diatas 80 berjumlah 31 
siswa dengan persentase 88,57\% . Sedangkan siswa yang mendapat skor kurang dari 80 berjumlah 4 siswa dengan persentase $11,43 \%$ dan nilai rata-rata skor 82,71 .

e) Hasil belajar siswa kelas XI IPS 1 MAN 2 Kota Bima dengan penerapan metode inkuiri melalui pengamatan situs sejarah Bima pada Siklus III.

Hasil pembelajaran dengan penerapan metode Inkuiri pada siklus III ini berdasarkan data yang didapat, menunjukan bahwa siswa yang mencapai KKM diatas 75 atau nilai diatas 75 sebanyak 35 orang siswa dengan persentase $100 \%$. Sebaliknya siswa yang belum mencapai KKM mendapatkan nilai kurang dari 75 sebanyak 0 orang siswa, dengan nilai rata-rata 82,85 Setelah diadakan tindakan pada siklus III sudah menunjukan hasil belajar yang bagus dan ketuntasan mencapai maksimal yaitu semua siswa tuntas.

f) Kecintaan siswa kelas XI IPS 1 MAN 2 Kota Bima dengan penerapan metode Inkuiri melalui pengamatan situs sejarah di Kota Bima pada Siklus III. Pelaksanaan pembelajaran dengan penerapan metode Inkuiri pada siswa kelas XI IPS 1 MAN 2 Kota Bima. Setelah diadakan pengisian angket secara individual hasilnya adalah sebagai berikut. Siswa yang mendapat skor sama atau diatas 80 berjumlah 35 siswa atau dengan kata lain mencapai 100 persen. Sedangkan siswa yang mendapat skor kurang dari 80 berjumlah 0 siswa. Ratarata skor 84,57.

\section{PEMBAHASAN}

Penelitian ini dilaksanakan dalam tiga siklus dengan menggunakan penerapan metode inkuiri melalui pengamatan situs sejarah di kota bima untuk meningkatkan hasil belajar dan menumbuhkembangkan kecintaan pada bangunan bersejarah. Penelitian ini dilaksanakan sesuai dengan prosedur penelitian tindakan kelas (PTK) yang telah ditetapkan diawali dengan perencanaan, pelaksanaan tindakan, observasi dan evaluasi, dan refleksi.

Oleh karena itu berdasarkan hal tersebut diatas, pembelajaran setelah diadakan tindakan yang berlangsung melalui tiga siklus berlangsung dengan efektif dan menyenangkan yaitu dengan penerapan pelaksanaan Metode Inkuiri melalui pembelajaran sejarah berbasis situs-situs sejarah Bima pada siswa kelas XI IPS 1 MAN 2 Kota Bima. Karena guru harus kreatifitas dan berinovasi dalam mengajar. Terlebih mata pelajaran sejarah adalah suatu mata pelajaran yang harus menyampaikan hal yang bersifat abstrak. Oleh karena itu seorang guru sejarah perlu mengembangkan cara-cara pendekatan pengajaran yang bisa membantu siswa menangkap peristiwa secara bermakna ( I Gde Widja, 1989: 97). Pendekatan disini adalah suatu metode yang melibatkan siswa untuk mencari sendiri suatu permasalahan yang muncul kemudian mencari datanya dan mengolahnya dan akhirnya membuat suatu kesimpulan berupa suatu laporan atau hasil karya. Pendekatan semacam ini adalah pendekatan yang banyak melibatkan siswa, dalam hal penggunaan metode Inkuiri.

Uji coba disiklus I tampak sekali pada siswa bahwa mereka ingin sekali suatu proses pembelajaran yang berbeda dari yang sudah-sudah walaupun juga nampak disiklus I siswa belum begitu bisa memanfaatkan waktu sebaik-baiknya sebagai kesempatan bertanya pada saat diskusi tidak dimanfaatkan dengan baik. Siswa masih merasa minder untuk bertanya, hal ini dikarenakan belum siap atau belum terbiasa dengan situasi baru apalagi bertanya yang selama ini kurang termotivasi dan hanya segelintir orang siswa saja.

Disiklus II siswa sudah mulai merasa senang dan bisa memanfaatkan waktu sebaik-baiknya. Yang bertanya banyak ketika dibuka diskusi dan suasana nampak hidup. Jelas terlihat siswa sudah mulai bisa beradaptasi dengan situasi yang baru. Terlebih lagi disiklus III pembelajaran semakin hidup dan semakin ramai. Siswa bukan hanya sekedar beradaptasi dengan situasi pembelajaran ini akan tetapi lebih kearah siswa semakin senang dan bergairah untuk belajar.

Dari penelitian tersebut juga bisa disimpulkan bahwa kelas yang ramai adalah tidak ada masalah selama kelas tersebut terdapat siswa yang saling menyanggah, saling mempertahankan pendapatnya dan saling ingin pendapatnya merasa didengar terlebih dahulu. Situasi pembelajaran yang seperti inilah yang sebenarnya disebut kelas yang hidup yaitu suatu kelas yang terkesan ramai. Hal ini sesuai dengan jenis-jenis aktifitas dalam kelas oral activities yaitu menyatakan, merumuskan, bertanya, memberi saran, mengeluarkan pendapat, diskusi, interupsi ( Paul B. Diedrich dalam Nasution, 1995:91). Padahal yang diketahui selama ini pembelajaran yang baik adalah situasi 
dimana kelas nampak sunyi, tenang, diam, dan hanya terdengar suara guru yang mengajar.

Kaitannya dengan penyajian pada saat presentase juga mengalami kemajuan yang bagus. Kelompok yang awalnya hanya juru bicaranya saja yang aktif sebagaimana terjadi disiklus I, dalam perkembangannya semua anggota bisa aktif saling membantu jawaban sebagaimana tergambar disiklus II dan III. Peserta didik yang sehariharinya biasapun unjuk bicara dalam rangka memberikan penjelasan sesuai dengan pengetahuannya. Sedangkan penyajian hasil karya yang dipaparkan sangat bagus dan bervariatif. Kreatifitas ditunjukan pada masing-masing kelompok. Dengan demikian langkah-langkah metode Inkuiri dapat dilaksanakan dengan efektif mulai dari perumusan masalah yang dibuat bersama guru, pengambilan hipotesis, pencarian data sampai pada pengolahan data kemudian pengambilan kesimpulan berupa hasil karya yang siap untuk dipresentasekan. Ternyata strategi pembelajaran dengan menggunakan metode Inkuiri dapat meningkatkan ilmu pengetahuan, daya kreatifitas dan kepandaian mengolah informasi ( Dahlan, 1999:160).

Dari uraian diatas, dapat diketahui bahwa metode inkuiri dengan melalui pengamatan situs sejarah di Kota Bima dapat meningkatkan hasil belajar siswa kelas XI IPS 1 MAN 2 Kota Bima tahun pelajaran 2014/2015, dan menumbuhkan kecintaannya pada bangunan bersejarah.

\section{SIMPULAN DAN SARAN}

\section{SIMPULAN}

Berdasarkan hasil penelitian dan pembahasan yang diperoleh dari siklus I, II, dan III, peneliti simpulkan bahwa dengan penerapan metode inkuiri dapat meningkatkan hasil belajar dan menumbuhkembangkan kecintaan pada bangunan bersejarah di Kota Bima pada siswa kelas XI IPS 1 MAN 2 Kota Bima.

Adapun hasil penelitian yang di peroleh dari siklus, I, II, dan III ditunjukan dengan adanya peningkatan hasil belajar siswa melalui evaluasi dari hasil post test dan kecintaan pada bangunan bersejarah melalui penyebaran data angket. Hasil persentase evaluasi belajar siswa pada Siklus I sebesar $77,14 \%$ dengan nilai rata-rata 75,02 , Siklus II sebesar $85,71 \%$ dengan nilai rata-rata 79 , sedangkan siklus III sebesar 100\% dengan nilai rata-rata 82,85. Kemudian berdasarkan data angket yang disebarkan setiap akhir siklus dapat diperoleh mulai dari siklus I sebesar 77,14\% dengan nilai rata-rata 80,54 , siklus II sebesar 88,57\% dengan nilai rata-rata 82,71, sedangkan siklus III sebesar $100 \%$ dengan nilai rata-rata 84,57.

\section{SARAN}

Berdasarkan hasil penelitian yang di peroleh, maka peneliti dapat memberika saran-saran sebagai berikut:

\section{a) Kepada guru}

Pada pembelajaran sejarah dikelas XI IPS 1 MAN 2 Kota Bima diharapkan agar guru dapat meningkatkan pengetahuan atau memilih metode yang sesuai dengan materi pembelajaran yang dapat meningkatkan hasil belajar siswa.

Dalam penelitian ini disarankan kepada guru sejarah secara khusus agar dapat menerapkan metode Inkuiri pada pembelajaran sejarah melalui pengamatan situs sejarah Bima dalam rangka untuk meningkatkan hasil belajar siswa dan menumbuhkembangkan kecintaan pada bangunan bersejarah di Kota Bima.

\section{b) Kepada kepala sekolah}

Sekolah diharapkan mampu memberikan pelatihan-pelatihan kepada guru untuk menguasai atau memahami lebih mendalam tentang metode pembelajaran dalam rangka untuk meningkatkan profesionalisme guru.

Sekolah diharapkan mampu meningkatkan motivasi belajar siswa, terutama dalam kegiatan proses belajar mengajar melalui himbauan kepada guru mata pelajaran agar menggunakan metode pembelajaran yang relevan dengan karakteristik materi pelajaran yang akan disampaikan.

\section{c) Kepada siswa}

Setelah menerapkan metode Inkuiri pada pembelajaran sejarah melalui situs sejarah di Kota Bima diharapkan siswa untuk lebih mencintai dan melestarikan peninggalan bersejarah dengan tidak merusak atau mencoret-coretnya karena merupakan warisan budaya dari nenek moyangnya.

\section{d) Kepada peneliti}


1) Supaya diadakan penelitian serupa pada materi pokok yang lain serta melibatkan variabel yang lebih banyak lagi.

2) Supaya diadakan penelitian tentang fakta-fakta lain yang berperan dalam meningkatkan hasil belajar siswa.

3) Kepada peneliti yang akan melanjutkan penelitian ini, keterbatasan-keterbatasan pada penelitian ini berupa pengambilan hasil belajar siswa supaya dikaji lebih mendalam sehingga penelitian dapat sempurna.

\section{DAFTAR RUJUKAN}

BNSP. 2007. KTSP Departemen Pendidikan Nasional.

Dahlan MD. Prof. Dr.1990. Model-model mengajar (Beberapa Alternatif Interaktif Belajar Mengajar). Bandung CV Diponegoro.

Depdiknas. 2007. Pendekatan Kontekstual (Contextual Teaching and Learning). Jakarta: Ditjen Dikdasmen.

Hariyono, Prof. Dr. M.Pd. 2011. Pembelajaran Sejarah dan Revitalisasi Nasionalisme. Solo.UNS.

Ihat Hatimah, Dra. M.Pd.2007. Pembelajaran berwawasan Kemasyarakatan. Jakarta Universitas Terbuka.

Miles, Matthew. B \& Huberman, A Michael. 2009. Analisis Data Kualitatif. UI Pres.

Moleong, Lexy J. 1998. Metodologi Penelitian Kualitatif. Bandung Remaja Rosdakarya.

Nana Sudjana, Dr. 2008. Dasar-dasar Proses Belajar. Bandung Sinar Baru.

Nanang Hanafiah \& Cucu Suhana. 2010. Konsep strategi Pembelajaran. Bandung: PT Refika Aditama.

Sancaka Dwi Supani, 2009. Situs Pati Ayam Sebagai Alternatif Sumber Belajar Sejarah Bagi Peserta Didik Sma. Tesis Pascasarjana Uns.(Unpublished).

Sartono Kartodirjo, 1992. Pendekatan Ilmu Sosial dalam Metodologi Sejarah. Jakarta: Gramedia Pustaka Utama.

Sarwiji Suwandi, H. Dr. M.Pd, 2009. Penelitian Tindakan Kelas (PTK) dan Penelitian Karya Ilmiah: Solo UNS.

Slameto, Drs, 1995. Belajar dan Faktor-faktor yang mempengaruhi. Jakarta: Rineke Cipta.

Suharsimi Arikunto, Prof. Dr. Dasar-dasar Evaluasi Pendidikan. Jakarta: Bumi Aksara.

Syahrir Yusi, 2006. Metode Penelitian Ilmu Sosial Pendekatan Kuantitatif. PT. Citrabook Indonesia.

Syaifuddi Azwar, MA. Dr. 2011. Tes Prestasi. Yogyakarta: Pustaka Pelajar.

Tilaar, H.A.R. Standarisasi Pendidikan Nasional. Jakarta: Rineke Cipta.

Udin S. Winataputra, dkk. 2008. Materi dan Pembelajaran IPS. Jakarta Universitas Terbuka.

Zulkarnaen. 2008. Kemampuan Guru dalam memilih Materi dan Metode Pengajaran Sejarah. UNJ. Program Pascasarjana. 